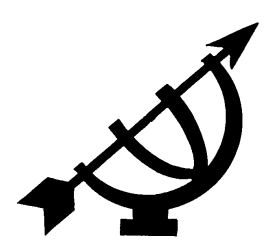

\title{
Multidimensionaliteit en die multikulturele situasie
}

\author{
Michael Heyns \\ Skool vir Filosofie \\ Potchefstroomkampus \\ Noordwes-Universiteit \\ POTCHEFSTROOM \\ E-pos: Michael.Heyns@nwu.ac.za
}

\begin{abstract}
Multidimensionality and the multicultural situation

Most societies and social institutions are currently characterised by the presence of a multitude of cultures which is an indication of a multicultural situation. Two opposite reductionist proposals for dealing with this situation are those of homogenisers/ universalists and fragmentists/particularists. There is also a dualistic in-between group. The question of this article has two sides: diagnostically it asks about the nature of the reductionism of the three groups. Therapeutically the question is about the conditions for overcoming this reductionism. Diagnostically it is argued that the reductionists deal in a one-sided way with two sets of abstractions of the multicultural situation. More precisely: they do not succeed in holding simultaneously onto important dimensions like coherence and diversity, as well as universality and particularity. Therapeutically it is argued that the latter dimensions of the multicultural situation must be mutually engaged in order for them to empower one another. It is proposed that this can be accomplished by a clear distinction between universal types like culture, justice, morality and so on, and also between these types and their particular manifestations. Furthermore, reductionisms as well as the disengagements of dualism can be avoided if the relationprinciples of parataxis, complementarity and acculturation are adhered to.
\end{abstract}




\section{Opsomming}

\section{Multidimensionalitieit en die multikulturele situasie}

Die meeste samelewings en sosiale instellings word tans gekenmerk deur die teenwoordigheid van 'n verskeidenheid kulture wat dui op 'n multikulturele situasie. Twee teenoorgestelde reduksionistiese voorstelle vir die hantering van hierdie situasie is dié van homogeniseerders/universaliste en fragmentiste/partikulariste. Daar is ook nog 'n dualistiese tussen-in groepering. Die vraag van hierdie artikel het twee kante: diagnosties word gevra na die aard van die reduksionisme van die drie groepe. Terapeuties word gevra na die voorwaardes om hierdie reduksionisme te oorkom. Diagnosties word geargumenteer dat die reduseerders geneig is om eensydig te werk te gaan ten opsigte van twee stelle kante of abstraheringe van die multikulturele situasie. Meer presies: hulle slaag nie daarin om gelyktydig vas te hou aan belangrike dimensies soos samehang en verskeidenheid, asook universaliteit en partikulariteit van hierdie situasie nie. Terapeuties word geargumenteer dat laasgenoemde dimensies van die multikulturele situasie bymekaar ingeskakel moet word sodat hulle mekaar wedersyds kan bemagtig. Daar word voorgestel dat dit bereik kan word deur 'n duidelike onderskeid te maak tussen universele soortlikhede soos kultuur, geregtigheid, moraliteit, ensovoorts, en tussen hierdie soortlikhede en die partikuliere manifesterings daarvan. Daarby sal reduksionisme asook die ontkoppeling van dualisme ontkom kan word indien voldoen word aan die relasiebeginsels van neweskikking, komplementariteit en akkulturasie.

\section{Inleiding}

Tans word die meeste samelewings gekenmerk deur 'n lewensbeskoulike, etniese, rassige, godsdienstige en talige verskeidenheid.1 Daarby dra die emansipasie van vroue en homoseksueles ook by tot wat algemeen 'n multikulturele situasie genoem word. Hierdie situasie waar 'n veelheid groepe, met elkeen 'n eie manier van doen (kultuur), hulself in dieselfde ruimte bevind, verskerp omdat globalisering besig is om nasionale lewensruimtes te rasionaliseer (nou eerder enkele streke teenoor die ouer bedeling van 'n veelheid nasionale state) en deur middel van die tegnologieë van kommunikasie en vervoer meer kompak te maak.

$1 \quad$ Vergelyk Fukuda-Parr (2004:2) vir 'n soortgelyke stelling. 
Ek gaan in hierdie artikel enkele homogeniserende/universalistiese, fragmentistiese/partikularistiese en tussen-in standpunte oor hoe om hierdie situasie op 'n regverdige wyse te hanteer, kortliks aan die orde stel en beoordeel. Meer spesifiek kan die probleemstelling in diagnostiese en terapeutiese kante verdeel word. Diagnosties sal gevra word na die aard van die eensydighede (d.i. die reduksionismes/verabsoluteringe) van laasgenoemde drie groepe. Tegelyk sal ook terapeuties gevra word na die voorwaardes vir 'n nie-eensydige kyk na die multikulturele situasie. 2

Aan die diagnoserende kant is my hipotese dat die onderskeie eensydige standpunte mank gaan aan 'n tweeledige redusering. Eerstens word samelewingsfere en -instellings in verskillende grade tot óf die universele strukture daarvoor, óf die partikuliere manifesteringe daarvan, gereduseer. Daarby is daar ' $n$ neiging om die kern van menswees en menslike saamleef met net 'n enkele lewensmodus te assosieer. So byvoorbeeld sal universaliste poog om die kulturele aspek van die samelewing met die partikuliere te identifiseer, wat dan uitgewan moet word deur 'n vermeende universele aspek soos die ekonomiese of rasionaliteit tot die kern van saamleefaktiwiteite te verhef.

Terapeuties lyk die poging om gelyktydig aan die verskeidenheid kulture en die samehang daartussen vas te hou, na die mees aanvaarbare. ${ }^{3}$ Hierdie verskeidenheid-én-samehang-standpunt kan verder op die spits gedryf word deur die verbandhoudende uitgangspunt dat gelyktydig aan die abstraheringe, "partikulariteit" en "universaliteit" reg moet geskied. Verskeidenheid, so sal geargumenteer word, is iets wat onder andere bestaan omdat 'n spesifieke kultuur 'n partikulariteit vertoon wat verhoed dat dit summier na ander kulture herlei kan word. Tog bestaan die samehang tussen kulture onder andere daarin dat hulle konstantgemeenskaplike (universele) eienskappe vertoon. Ook hier sal geargumenteer word dat die billikste standpunt is om aan sowel die universele as die partikuliere 'n regmatige plek te gee.

Hierdie uitgangspunt kan verder verfyn word deur aandag te gee aan die transendentale vraag na die voorwaardes vir 'n wedersydse

$2 \quad$ Dit is 'n soortgelyke vraag wat op 'n terloopse wyse ook deur Vogel (1993:328329) en Descombes (1994:112) gevra word.

3 Vgl. byvoorbeeld die standpunte van Balslev (1991:3-4), Griffioen (1994:12-15), Bohman (1998:204) en Fukuda-Parr (2004:2). 
inskakeling tussen eenheid en verskeidenheid, asook universaliteit en partikulariteit. Ek gebruik "bymekaar inskakel" as die Afrikaanse ekwivalent van die Engelse engagement. Daarby gaan ek veral klem lê op die metaforiese betekenis van engagement as die "inskakeling van ratte". Die Oxford Dictionary verduidelik dit as die aksie "to interlock ... so that it transmits power". Die inskakeling van die multidimensies van die multikulturele situasie bymekaar het dus ten doel die wedersydse bemagtiging van partikulariteit, universaliteit, eenheid en verskeidenheid as dimensies van die multikulturele situasie. Aan die einde van die artikel sal aandag gegee word aan sommige van die voorwaardes vir sodanige inskakeling.

\section{Onderskeidings}

Ten einde aan die diagnose wat hier onder gedoen gaan word 'n lewens- en wêreldbeskoulike rigting te gee en so 'n begin te maak met 'n terapie vir die multikulturele situasie, kan by Griffioen (1994:18; 1995:214-223) se onderskeid ten opsigte van soorte pluralismes aangesluit word. Hy wys eerstens op 'n pluraliteit van rigtings; dit is die verskeidenheid uiteenlopende religieë, lewens- en wêreldbeskouings en denksisteme wat gekenmerk word deur 'n feitlik onversoenbare onderlinge konflik. Hierdie konflik word veroorsaak deur die totalitêre karakter van 'n bepaalde rigting. Uiterstes soos universalisme en partikularisme sal in hierdie kategorie geplaas kan word en afgewys word as verabsoluterings wat ideologiese afmetings aanneem. Teenoor rigtingpluralisme onderskei Griffioen ook 'n kontekstuele en strukturele pluraliteit. Die soortlike identiteite waarop hieronder gewys sal word, kan in die kategorie "strukturele pluraliteit" geplaas word. Ek sal deurgaans veronderstel dat die partikuliere manifesterings van hierdie soortlikhede verband hou met die kontekstuele pluraliteit. Belangrik is die feit dat Griffioen suggereer dat samehang (wedersydse inskakeling) ten opsigte van hierdie twee soorte pluraliteit redelik gemaklik gevind kan word.

'n Voorwaarde vir die vermyding van eensydige ontologieë is dat die abstraksies, universeel en partikulêr, wat in die werklikheid geïntegreerd met mekaar saambestaan en wat in 'n visie wat verabsoluterings (verafgodings) wil vermy, bymekaar ingeskakel moet word. Ten einde so 'n inskakeling te bewerkstellig moet hierdie abstraksies heel eerste van hulle gereduseerde vorms (universalisme en partikularisme) losgemaak word. Ten opsigte van die tema van hierdie artikel beteken dit dat die eie aard van 
onderskeidelik universaliteit en partikulariteit in die multikulturele situasie korrek geïdentifiseer sal word.

Laasgenoemde kan bereik word deur 'n onderskeid te tref tussen die strukture of norme vir en die entiteite waarvoor hierdie strukture/norme geldig is. Die populariteit van Hegel en Darwin in die moderne tyd het die partikularisme 'n historistiese kinkel gegee: geen duursame norme kan geïdentifiseer word nie, net 'n historiese stryd tussen partikulariteite vir die belangrikste plek as ontiese determineerder. Historisme gaan dus (soos die partikularisme) van die standpunt uit dat 'n universele dimensie nie bestaan nie. As alternatief vir ons intuïsie van universaliteit word die menslike kultuur uitgelewer aan 'n evolusieproses waarin die sterkste of grootste kultuur veruniversaliseer word. Dit is egter bedenklik om te veronderstel dat 'n kwantitatiewe onderskeid tussen groter en kleiner of sterker en swakker entiteite die plek kan inneem van die onderskeid tussen partikulariteit en universaliteit.

'n Boom kan byvoorbeeld nie die partikuliere wees terwyl die bos die universele verteenwoordig nie. Dit is eerder so dat hierdie spesifieke boom, ' $n$ boom is omdat dit die soortlike (universele) eienskappe van 'n boom vertoon, terwyl die bos waarvan die boom deel is, 'n bos is omdat dit die universele (soortlike) kenmerke van 'n bos vertoon (Taljaard, 1976:80-81). Net so kan nie gestel word dat die "mensdom" universeel is terwyl die Westerse kultuur 'n partikuliere manifestasie van die mensdom is nie. Die "Weste" is eerder 'n kollektiewe manifestasie van die soortlike kenmerk kultuur (in onderskeid van soortlike kenmerke soos godsdienstigheid, die ekonomiese, ensovoorts), terwyl die mensdom die kollektiewe manifestasie is van die soortlike identiteit menslikheid (in onderskeid van soortlike identiteite soos dierlikheid, plantaardigheid, goddelikheid, ensovoorts).

'n Verdere voorbeeld: Walzer (1994b:1-6, 63-64, 66-70, 74-75, 80-81) maak 'n onderskeid tussen minimale of "dun" universele norme en 'n "dik" (thick) etos, waar laasgenoemde die partikuliere inbedding en manifestering is van die "dun"-norme. Volgens hierdie onderskeid is die "dun"-norm wat in die multikulturele situasie ter sprake is, selfregering. Maar elke multikulturele situasie verskil van al die ander, wat beteken dat 'n "dik" etos voorsiening daarvoor sal maak dat hierdie beginsel in verskillende grade (en maniere) toegepas kan word na gelang van omstandighede.

Wanneer Walzer (1994b:63-67, 69-70, 74-75, 77-78, 80-81) selfregering as die norm vir die multikulturele situasie noem, is dit 
ook vir hom belangrik dat selfregering nie onbeperk kan wees nie. Selfregering kan nie gevoer word tot op die punt waar ' $n$ eindelose en absurde fragmentering van en konflik tussen menslike gemeenskappe intree nie. Dit is daarom belangrik dat selfregering ' $n$ teenwig sal hê in die vorm van verdraagsaamheid. Die universele kant van die norme vir die multikulturele situasie bestaan nie net uit 'n enkele norm nie. Aan die entiteitskant (d.i. die subjek waarvoor die verskeidenheid norme geld) is dit ook duidelik dat die multikulturele situasie 'n pluraliteit van kulture (d.i. manifesterings) veronderstel.

Dit is egter belangrik om Vincent $(2002: 160-162,164,172)$ se opmerking in gedagte te hou, naamlik dat die konsep multikulturalisme in die beskikbare literatuur nie 'n samehangende, konsekwente en eenduidige betekenis het nie. Hierdie onsamehangendheid bestaan omdat daar veral verwarring is rondom die konsepte kultuur en groep.

Vir die doeleindes van hierdie artikel kan kultuur met behulp van Rorty (1999:188-190) se verduideliking gedefinieer word. Kultuur is 'n gemeenskaplike stel gewoontes waarvolgens gehandel word en wat 'n gemeenskap bemagtig om met mekaar en die omgewing oor die weg te kom. Volgens hierdie begrip het elke weermagbarak, akademiese departement, tronk, ensovoorts 'n kultuur van sy eie. Die meeste mense behoort dus tot ' $n$ hele aantal kulture, omdat hulle tot meerdere sosiale instellings kan behoort. Hierdie verwarring kan opgelos word deur kultuur te sien as 'n soortlike modus van bestaan - 'n modus wat wel ook die soortlike identiteit van 'n bepaalde groep kan beïnvloed.

In navolging van hierdie tiperings kan kultuur verder verduidelik word deur daarna te verwys as die "vormgewende vermoë" (d.i. modus) wat mense besit ten opsigte van hulle natuurlike en sosiale omgewing. As produkte genereer kultuur fisiese dinge soos geboue en digbundels, maar ook die interpretasieraamwerk, etos en styl wat 'n bepaalde gemeenskap kenmerk. Hierdie kultuurprodukte kan op hulle beurt as die bron vir kultuur as vermoë funksioneer. Die vervoerinfrastruktuur van 'n land word byvoorbeeld die voorwaarde vir die verdere vormgewing aan die ekonomie van daardie land. Net so is die etos en interpretasieraamwerk van 'n gemeenskap die voorwaarde vir 'n gemeenskap se positivering van norme en wette.

Duidelike onderskeidings moet ook gemaak word rondom die konsep groep. As deel van sy poging om die grense vir kulturele partikulariteit uit te spel, argumenteer Walzer (1994b:82-83) dat 
mense 'n "verdeelde self" het wat veroorsaak word deur die verskillende groepe waaraan hy/sy behoort. 'n Persoon verwerf 'n komplekse identiteit omdat hy/sy tot meer as een gemeenskap behoort en sy/haar identiteit word dus deur dié veelheid geproduseer. Hierdie kommunitariese siening van Walzer oor die produksie van die self kan aangepas word met die idee dat 'n gemeenskap vorm rondom 'n bepaalde menslike funksie. Dit is dus nie net die gemeenskap wat die persoon vorm nie, maar die gegewe samestelling van menswees het ook ' $n$ vormende invloed op die gemeenskappe wat tot stand kom. 'n Taalgemeenskap vorm byvoorbeeld rondom die taalvermoë van mense - meer spesifiek 'n bepaalde taal. ' $n$ Staat sal vorm rondom ' $n$ bepaalde territoriale sfeer van reg en geregtigheid en 'n kerk rondom 'n bepaalde godsdienstige interpretasie en belewing, ensovoorts.

Voorts kan geargumenteer word dat laasgenoemde instellings en gemeenskappe hulle eie kulture vorm, soos Rorty verduidelik het. So byvoorbeeld kan die taalkultuur van 'n taalgemeenskap, 'n godsdienskultuur van 'n godsdiensgemeenskap, 'n opvoedingskultuur van 'n opvoedingsinstelling, ensovoorts van mekaar onderskei word. Alhoewel kultuur (as funksie en produk) nóú verbind is aan 'n gemeenskap (wat optree as draer van daardie kultuur) moet die twee van mekaar onderskei word. 'n Kultuur is nie 'n gemeenskap nie. Elke samelewingsverband of gemeenskap sal egter 'n eie styl en etos asook fisiese kultuurprodukte produseer.

Die onderskeid tussen 'n verskeidenheid gemeenskappe is belangrik ten einde die verskynsel van 'n totalitaristiese kultuur te identifiseer. 'n Soortlike gemeenskap wat pretendeer om alle funksies (byvoorbeeld godsdiens, onderwys, administrering van geregtigheid, ensovoorts) te omvat, het totalitaristies ontspoor. Dus sal die kultuur van so 'n totalitaristiese, soortlike gemeenskap wat 'n totalitêre aanspraak maak (so asof dit byvoorbeeld die totale etos en interpretasieraamwerk van 'n persoon kenmerk) ook as ontsporing getipeer kan word. Dit gun immers die kulture van die persoon se ander funksionerings (en die gemeenskappe wat hierdie kulture dra) geen bestaansruimte nie.

'n Persoon sal in 'n volledig gedifferensieerde situasie daarop aanspraak kan maak dat hy die produk en draer is van verskillende kulture. Vir hierdie rede is dit noodsaaklik om genuanseerd te praat van byvoorbeeld die "Westerse kultuur" omdat dit eerder 'n konfigurasie is van verskillende "kulture" wat mekaar beïnvloed. Dit is daarom ook 'n totalitaristiese dwaling om na iemand te verwys as Westerling of Afrikaner as hiermee bedoel word 'n soort 
gesentreerde of omvattende identiteit wat al daardie persoon se funksioneringe omvat. Afrikaner verwys in die huidige konteks waarskynlik na 'n talige identiteit wat 'n persoon het omdat sy talige vermoë gevorm is deur 'n bepaalde taalgemeenskap. Hierdie identiteit sal wel die persoon se ander identiteite beïnvloed, maar nooit totaal beheer nie. Alleen in so 'n beperkte betekenis kan ruimte gelaat word vir die feit dat Afrikaners ook verskillende geloofsoortuigings, staatlike nasionaliteite, seksuele oortuigings, ensovoorts handhaaf.

\section{Monisme}

Die onderskeidings wat hier gemaak is, kan gebruik word as diagnostiese instrument wanneer krities gekyk word na 'n aantal voorstelle oor hoe om die multikulturele situasie te hanteer. Daar sal eerstens gekyk word na 'n aantal monistiese voorstelle waarin kru reduserings na óf die universele óf die partikuliere, asook na enkele soortlikhede, duidelik blyk.

\subsection{Partikularisme}

'n Berugte, ouer partikularistiese standpunt oor die multikulturele situasie is dié van Adolf Hitler. Hy het ras die essensiële identiteit van alle menslike funksioneringe gemaak - dit is sy eerste redusering. Hy gaan egter verder en sonder 'n spesifieke ras (Duitsers) uit as die essensiële ras en juis hierdie verdere redusering maak van hom 'n partikularis. Oor die staat argumenteer Hitler (1939:324-332) byvoorbeeld dat dit nie 'n magsinstrument kan wees ter wille van die bewaring van vrede nie, want dan sou dit die gevaar loop om ' $n$ instelling te word net ter wille van gesag. Hy reageer meer positief oor die moontlikhede dat die staat 'n magsinstrument is wat die ekonomiese welsyn en 'n eenvormige kulturele identiteit moet bevorder. Tog meen hy dat 'n fokus op hierdie aspekte die eintlike faktor wat ook kultuur en ekonomie sou bevorder, ondermyn. Daarom stel hy dat die staat in die eerste plek 'n magsinstelling moet wees wat die ras-identiteit van mense bevorder en veilig stel - hy het veral in gedagte wat hy noem die "Duitse element". Volgens Hitler is die skep van kulturele waardes en beskawing afhanklik van die ras wat aanleiding tot die gewensde waardes gee. Die hoofdoel van die staat moet dus wees om die Duitse ras te bewaar en te verbeter. Indien die staat nie hierdie funksie vervul nie, moet dit as sleg beoordeel word, omdat dit die voorwaardes of potensiaal vir 'n superieure beskawing vernietig. 
Hitler het ras die omvattende of fundamentele soortlikheid gemaak van waaruit alle funksionerings, instellings en identiteite van die samelewing organies moet groei. Daarby het hy hierdie kategorie verder vereng deur 'n enkele manifestering daarvan, naamlik die ras van die meerderheid Duitsers, in die sentrum te plaas. Hoewel die beheptheid met 'n spesifieke ras en die skep van eksklusiewe gemeenskappe op grond van ras lankal nie meer aanvaarbaar is nie (omdat dit sonder uitsondering gelei het tot die verdrukking van diegene wat nie tot die gewensde ras behoort nie), is die logika van hierdie partikularisme nie totaal onbekend nie. Vandag nog is daar samelewings waar 'n enkele religieuse (byvoorbeeld verskeie Midde-oosterse lande) of talige (waarskynlik Frankryk en die VSA4) kultuur uitermate bevoordeel word, omdat so 'n gesentreerde kultuur of religie as deurslaggewend vir die welsyn van die betrokke samelewing of beskawing gesien word. Hierdie partikularistiese variante verteenwoordig egter ' $n$ visie wat uiteindelik net realiseer met 'n stewige dosis dwang en konflik.

'n Resente teoretiese uitwerking van laasgenoemde reduserings kan gevind word in die invloedryke Clash of civilizations van Samuel P. Huntington wat die huidige globaal-politieke verwikkelinge tot die kultureel-religieuse beperk. Huntington (2002:29-36) stel dat tydens die Koue Oorlog die ekonomiese ideologieë van die kapitalisme en die kommunisme die hoofbron van konflik en invloed op ons wêreld was. Na die val van die kommunisme in Oos-Europa blyk dit egter dat die groot konflikte nie meer tussen Oos en Wes is nie, maar meestal tussen arm lande. Die paradigma van die Koue Oorlog, wat die wêreld in 'n konflik tussen ryk en arm verdeel het, dra nie meer die swaarste gewig nie. Die idee dat ons 'n konfliklose wêreldeenheid binnegaan (globalisering) waar 'n liberale en kapitalistiese demokrasie oorheers (en dat ons by die einde van ideologiese stryd aangeland het), is ook invloedryk, maar word weerspreek deur 'n duisternis etniese konflikte oor die hele wêreld. Huntington (2002:21, 28-29) betoog dat ons eerder moet raaksien dat patrone van kohesie, disintegrasie en konflik tussen sewe of agt groot beskawings tans die hoofinvloed op die wêreld is. Hy (Huntington, 2002:41-44) beskryf 'n beskawing as 'n kulturele entiteit waarin dit gaan oor die lewenswyse van mense. Hierdie lewenswyse sluit in die waardes, norme, instellings, denkwyse, taal en veral die religie

4 Vgl. byvoorbeeld Kymlicka (1997:23-24) se tipering van die VSA-regering se homogeniserende taalpraktyke. 
van mense. Om die waarheid te sê, hy sien religie as die kern van die sewe of agt groot kulturele entiteite wat in konflik met mekaar is.

In die konteks van hierdie artikel is die probleem met Huntington se beskrywing nie soseer dat hy nie die huidige situasie korrek beskryf nie, maar dat hy nie eintlik poog om meer gedifferensieerde en moontlik bevrydende tendense van onderskeid en kohesie tussen groepe mense te verken nie.

\subsection{Universalisme}

In die beskrywing van bogenoemde partikularismes word 'n bepaalde manifestasie van óf rassige, óf etniese, óf talige, óf godsdienstige kultuur die bron en filter vir alle sosiale relasies en sosiale funksies. Dit wil sê alle werk, ekonomiese aktiwiteit, gesinslewe, ontspanningsbedrywighede, opvoeding, ensovoorts word deur die bril van so 'n sentrale identiteit en groepering gesien. Maar dit is nie net partikulariste wat menswees op hierdie manier na 'n enkele modus van bestaan reduseer nie. Die universalistiese kosmopoliete waarna vervolgens gekyk gaan word, doen dit ook, maar dan met die veronderstelling dat die soortlike aspek wat hulle uitkies as die kern en bron van menswees, nie gebuk (behoort te) gaan onder verskille tussen partikuliere manifesterings nie.

Karl Marx is 'n voorbeeld van 'n moderne kosmopoliet wat gepoog het om die essensiële modus van die menslike bestaan te identifiseer, met die veronderstelling dat hierdie sentrum geensins enige verskille moet toon in die partikulêre manifesterings daarvan nie. Marx (1959:4, 9-14, 30-34) is byvoorbeeld van mening dat godsdiens 'n teken is van bekrompenheid. Meer nog, godsdiens, privaatbesit (en waarskynlik ook kulturele en nasionale affiliasie) is simptome van die algemene onvryheid van die mens; dit is teken van ' $n$ immorele egoïstiese bestaan. Marx sien hierdie saak in 'n universalistiese lig: sy doel is om van godsdienste soos die Judaïsme en die Christendom ontslae te raak. Hy gee selfs die soortlik reduserende tree as hy die ware bestaan as 'n politieke bestaan definieer, wat impliseer dat die mens van godsdiens in die algemeen ontdaan moet word. Hy het egter nie net sy mes in vir 'n premoderne bedeling waar godsdiens sentraal in die lewens van mense gestaan het nie, maar hy het dit veral teen die moderne bourgeoisie wat die samelewing in 'n openbare en 'n private sfeer verdeel het. Volgens hierdie verdeling kan 'n persoon steeds 'n bekrompe godsdiens en selfsugtige privaatbesit bedryf, solank dit tot die private sfeer beperk is. In die openbare sfeer word die individu gesien as 'n skakel in die ketting van ware menslike lewe en verkry 
hy universaliteit. Die probleem is egter dat laasgenoemde openbare politieke bestaan, binne die liberale bourgeoisie se visie, onwerklik en abstrak is. Dit beteken byvoorbeeld dat die staat wel vry is van godsdiens, maar dat die burgers van die staat nog nie vry is van godsdiens nie. Marx wil dus 'n rewolusie hê wat 'n ware staat sal skep waar godsdiens en private besit afgeskaf sal word. Dit is 'n rewolusie waarmee die menslike natuur sodanig verander word dat 'n vermeende, onselfsugtige politieke bestaan moontlik word. Volledige menslike emansipasie word verkry slegs wanneer die abstraktheid van 'n openbare sfeer (in onderskeid van 'n private sfeer) opgehef word, en die individu besef dat hy lid van die menslike spesie is ('n openbaar-politieke bestaan het) ook in sy direkte alledaagse (private) bestaan. Dit beteken dat menslike bestaan volledig gereduseer kan word tot die kommunale sy daarvan.

Putnam (1996:91-93) wys daarop dat universalistiese argumente soos laasgenoemde gewoonlik stel dat sogenaamde partikularismes soos patriotisme en religie, lei tot chauvinisme, rassisme, fundamentalisme en onverdraagsaamheid, en daarom verdring behoort te word. Hierdie argument het gewoonlik 'n militante, kosmopolitiese en ateïstiese grondslag en veronderstel dat indien nie-kosmopolitiese en teïstiese tendense verwyder word, ons 'n minder wrede en agressiewe wêreld sal hê. Maar, volgens Putnam, is daar nie die geringste rede om dit te glo nie. Die USSR was veronderstel om kosmopolities te wees en was natuurlik ateïsties. Tog kan die slagoffers van Stalin se misdade so veel as vyftig miljoen mense wees.

Universaliste is ook te vind in die geledere van 'n liberale kosmopolitisme. Soos in die geval van Marx, word ook hier geargumenteer dat 'n universele menslikheid te vind is in 'n enkele menslike aspek. Nussbaum (1996a:7-8; 1996b:133) argumenteer byvoorbeeld dat dit reeds sedert die tyd van die Sinici en Stoïsyne duidelik is dat die onderskeidende, universeel menslike kenmerk sy rede is. Die saakmakende gemeenskap waarin die mens homself bevind, is die "gemeenskap van menslike argument wat die werklik grootse en werklik gemeenskaplike" is. Kritiek teen hierdie standpunt kan aansluit by die onderliggende individualisme daarvan ('n fokus op die "gemeenskap van menslike argument" is té abstrak om ernstig oorweeg te word as 'n rede vir kommunaliteit) en ook die groteske redusering van menswees tot die rede wat daarin veronderstel word.

Ten opsigte van die individualisme van die kosmopolitisme wys Vincent (2002:2-4) daarop dat kosmopolitiese liberales (soos 
Nussbaum) meesal van die veronderstelling uitgaan dat groepe nie betekenisvolle partikulariteite kan wees nie, omdat die individue die eintlik ware universele bestaandes is wat benewens ras, geslag, etnisiteit, ouderdom of nasionaliteit, almal gelyk is. Tog stel hy dit as 'n waarneming (en beklemtoon dat hy nie tribalisme wil vergoeilik nie) dat die "stam" (tribal group) die meer algemene ervaring van die meerderheid mense is. Dit beteken dat die liberale kosmopolitisme ernstig uit voeling is met die huidige sosiale en politieke realiteit. Volgens Vincent is daar ook die argument dat fragmentasie, verskil en die ontdekking van die eie gewoontes, wette en kultuur 'n positiewe waarde en politieke ontwikkeling verteenwoordig. Laasgenoemde argument is eweneens vir Vincent verdag, maar tegelyk die deurslaggewende realiteit.

Hoewel Vincent korrek is om partikularisme te verwerp, is ' $n$ relatiewe erkenning van kommunale partikulariteit nie iets wat sommer maklik van die tafel te vee is nie - veral nie indien 'n mens die uitstaande kritiek teen Nussbaum se standpunt ernstig opneem nie. Die kritiek is naamlik dat rasionaliteit in sy konkrete en partikuliere manifesterings kultureel en selfs religieus beïnvloedbaar is, en dat dit gevolglik nie vir almal dieselfde betekenis sal hê nie. Indien dit dus so is dat rasionaliteit in sy manifesterings nie immuun is ten opsigte van ander menslike eienskappe nie, beteken dit byvoorbeeld dat die sosiale inbedding van 'n mens net so 'n belangrike aspek van menswees is as rasionaliteit. 5

Die praktiese beswaar teen die suggestie dat kulturele partikulariteit grootliks geïgnoreer moet word, is die ervaring dat juis die nieerkenning van kulturele verskille meestal daartoe lei dat kulturele identiteite as deel van staatsbeleid brutaal onderdruk word deur middel van godsdienstige vervolging, etniese suiwering en alledaagse uitsluiting, asook diskriminasie op ekonomiese, sosiale en politieke gebied. Die geskiedenis van die twintigste eeu wys egter dat partikuliere kulture 'n hardnekkige veerkrag toon. Dit beteken dat die erkenning van partikuliere kulturele identiteite oënskynlike oneindige spanning en konflikte oplos. Dit hoef nie te beteken dat

$5 \quad$ Hierdie kritiek word op 'n eie manier deur Himmelfarb (1996:74-77), McConnell (1996:82-84) en Putnam (1996:93-96) teen Nussbaum se rasionalistiese motivering van 'n kosmopolitaanse standpunt uitgespreek. Dieselfde punt van kritiek is onderliggend aan Sandel (1984:83-87) se bekende ontmaskering van die liberale idee van 'n onbelaste (unencumbered) self wat hy tipeer as die pretensie om vry te wees van enige determinerings wat deur die natuur en menslike gemeenskap opgelê word. 
lojaliteit aan byvoorbeeld die staat daardeur ondermyn sal word nie. Die ervaring toon dat juis die teenoorgestelde gebeur (Fukuda-Parr, 2004:1-3).

\subsection{Monistiese reduserings}

Die verskil tussen bogenoemde universaliste en partikulariste is dat eersgenoemde dit wat hulle sien as 'n modus van bestaan, wat alle mense orals en in alle tye met mekaar in gemeen het, verabsoluteer (universaliseer) ten koste van al die beduidende verskille tussen hulle. Partikulariste aan die ander kant, het 'n obsessie met die unieke, die eie afsonderlike gemanifesteerde vorm van hierdie verabsoluteerde modus van bestaan in 'n spesifieke individu of gemeenskap.

Sowel universaliste as partikulariste maak hulle dus, bo en behalwe die redusering tot die universele of partikuliere, ook skuldig aan 'n tweede soort redusering, naamlik die inperking van menslike lewe tot ' $n$ enkele modus van bestaan. (Marx reduseeer byvoorbeeld menslike bestaan tot die politieke; Nussbaum tot die rasionele; Hitler tot die rassige en Huntington tot die kulturele.) Hierdie modus word uitgelig en as't ware ontkoppel uit 'n gelyke wederkerigheid met ander modi asof dit dié definiërende menslike funksie is. In sowel universalismes as partikularismes word die gemeenskap of sosiale verband wat rondom die verabsoluteerde aspek gevorm word, gesien as die primêre en selfs totalitêre invloed op die vorming van mense - dit is byvoorbeeld die staat as openbare sfeer, ' $n$ kosmopolitiese gemeenskap van "rasionele gesprek", ras of 'n beskawing. Dit beteken dat die "kultuur" van hierdie gemeenskap die dominante of totalitaristiese kleur van identiteit word.

Partikularistiese standpunte gaan oënskynlik verder as dié van universaliste, deur bo en behalwe die verabsolutering van 'n bepaalde menslike kenmerk (bv. ras) ook nog 'n partikuliere manifestasie van hierdie kenmerk (bv. die Duitse manifestering van ras) te beklemtoon. Die indruk word geskep dat mense wat deel het aan hierdie spesifieke manifestering volledig daarin afgesluit is, en dat ander identiteite en dus gemeenskaplikhede met ander mense nie moontlik is nie. Die uitsluitende effek van hierdie denkwyse eindig gewoonlik in 'n onderdrukking van diegene wat nie inpas in die uiters eng prentjie van menswees nie. (Rasseskeiding in SuidAfrika en die VSA, asook verskeie gevalle van etniese suiwering gedurende die twintigste eeu, is goeie voorbeelde hiervan.) 
Sommige mense wend hulle tot 'n universalisme om laasgenoemde gevolge van die eksklusiwisme vry te spring. Tog poog bogenoemde universaliste steeds sover moontlik om universaliteit te beperk tot 'n enkele aspek van menswees; aspekte soos religie, kultuur en nasionaliteit kan byvoorbeeld nie deel wees van wat hulle as universeel sien nie. Universaliste lê klem op die gemeenskaplike in die aspek waartoe hulle menswees reduseer, wat volgens hulle beteken dat geen verskille in die partikuliere manifesterings vertoon word nie.

Kenmerkend is egter dat ook universaliste brutaal reageer teen diegene wat weier om by dit wat hulle as die gemeenskaplike aspek (en manifesteringe daarvan) sien, in te val. (Vergelyk byvoorbeeld weereens die twintigste-eeuse kommunisme, asook die pogings van kulturele homogenisering in die VSA 6 en Frankryk.) Vermeende nieuniversele identiteite en groeperings word óf na die periferie verban, óf gedwing om hulle partikuliere identiteit af te sweer ten einde in te pas. Partikulariteite word met ander woorde gelyk gemaal of gehomogeniseer. By sowel universaliste as partikulariste kan onderdrukking van vermeende nie-essensiële funksies en identiteite dus neerkom op die vervolging van mense wat hierdie nieessensiële modi en identiteite belangrik ag. Daar is op hierdie punt dus weinig verskil tussen universaliste en partikulariste. 7

\section{Dualisme}

In die voorafgaande afdeling is gekonsentreer op kru reduserings van die multikulturele situasie tot óf die universele óf die individuele asook tot ' $n$ enkele modus van menswees en menslike saambestaan. Daar bestaan egter deesdae ook meer gesofistikeerde standpunte. Vervolgens sal gekonsentreer word op pogings wat redusering probeer vermy, maar dan tog vasval in dualismes wat steeds nie 'n werklike inskakeling van universaliteit en partikulariteit,

$6 \quad$ Young (1995:179-182) verduidelik byvoorbeeld dat diegene wat nie inpas by die beeld van 'n Christelike, blanke, Engelssprekende man nie, vroeër nie toegelaat was om deel te hê aan die Amerikaanse demokrasie nie. Hoewel nie meer so kru nie, word die publieke sfeer steeds gedefinieer as algemeen en identiteite wat nie tot laasgenoemde konformeer nie, word gedwing om dit te doen.

$7 \quad$ Walzer (1996:126-127) formuleer die praktiese konsekwensie van albei soos volg: "The crimes of the twentieth century have been committed alternately, as it were, by perverted patriots and perverted cosmopolitans. If fascism represents the first of these perversions, communism, in its Leninist and Maoist versions, represents the second." 
asook 'n inskakeling van verskillende soortlikhede bymekaar, toelaat nie. Die eerste groepering waarna gekyk sal word, is geneig om die universele hoër te ag as die partikuliere en om die historiese (kulturele) aspek van menswees 'n groter plek te gee as enige ander lewensmodus - vandaar die tipering van hierdie groep as historisme. Die tweede groepering is kommunitariste wat die invloed van menslike saambestaan (die sosiale) hoër ag as die meeste ander menslike aspekte en tegelyk ook 'n sterker invloed aan die partikuliere toewys.

\subsection{Historisme}

Historiste is soms bewus daarvan dat hulle hulle gunsteling lewensmodus in die vorm van die parochiale manifestering daarvan universaliseer. Rockefeller (1994:87-92) byvoorbeeld, glo in die universaliteit van liberale waardes, maar stel tegelyk dat die idee van die neutraliteit van die liberalisme 'n "gevegskreet" is van spesifiek die Westerse kultuur. Hy regverdig laasgenoemde partikularistiese neiging met die aanspraak dat die liberalisme die vermoë het om alle mense te bevry. Hy gaan voort om te verkondig dat kulturele identiteit nie deel van die essensiële menslikheid van mense kan wees nie. Om byvoorbeeld mense se etniese identiteit op 'n gelyke voet met liberale waardes te sien, is om die deur te open vir onverdraagsaamheid. Daarom word kultuur eerder gesien as 'n soort aanhangsel wat nie eintlik in die prentjie van liberale neutraliteit inpas nie. Tog is dit iets wat nie weggewens kan word nie en hy argumenteer selfs dat dit in die aard van 'n liberale demokratiese kultuur is om etniese identiteite te respekteer en nie te onderdruk nie. Oakes (1993:3) is waarskynlik reg as hy hierdie standpunt as onsamehangend kritiseer. Wat Rockefeller toegee aan die verdraagsaamheid van verskille, maak hy ongedaan deur dít wat hy as 'n universele menslike natuur sien, onaanvegbaar te stel. Hierby kan gevoeg word dat hy aan die een kant veronderstel dat liberale waardes soos bevryding parochiaal is, maar aan die ander kant veronderstel dat dit veruniversaliseer moet word. Rockefeller se standpunt gaan mank aan ' $n$ dualisme waarin die universele en partikuliere mekaar voortdurend weerspreek.

Hierdie dualistiese onvermoë om die partikuliere en universele by mekaar in te skakel, is oënskynlik 'n chroniese patroon by kontemporêre denkers. Walzer (1994a:99-103) verduidelik byvoorbeeld dat die huidige denke oor liberalisme 'n onderskeid maak tussen 'n klassieke liberalisme wat individuele regte asook 'n kultureelreligieus neutrale staat beklemtoon, aan die een kant, en 'n 
kommunitariese liberalisme wat ruimte maak vir die oorlewing en opbloei van 'n bepaalde kultuur en lewensbeskouing (d.i. die Westerse kultuur) aan die ander kant. Volgens laasgenoemde kommunitariese liberalisme is keuses moontlik en een van die keuses is om te kies vir die beklemtoning van die klassieke liberalisme. Walzer argumenteer volgens laasgenoemde keuse dat hy nie daarvan sal hou as voorsiening gemaak word vir minderhede om openbare geld te gebruik om byvoorbeeld afsonderlike skole te bedryf nie. Sy partikularistiese keuse vir 'n universalistiese en neutrale liberalisme impliseer dat die pluraliteit van kulture vry is om te probeer oorleef, maar dat hulle nie hulp daarmee van die staat moet verwag nie. Alle kulture moet dieselfde risiko loop, hoewel hy toegee dat sommige 'n groter risiko loop, omdat hulle nie die mag, getalle en geld kan mobiliseer wat die groter kulture tot hulle beskikking het nie.

Laasgenoemde erkenning is ' $n$ aanduiding dat Walzer waarskynlik bewus is van die spanning in sy standpunt, naamlik dat hy probeer om 'n universalisme (gelykheid) te bevorder op die basis van 'n partikularisme (die liberalisme). Hierdie gevoel dat alles nie pluis is met so 'n veruniversaliseerde partikularisme nie, word ook deur Taylor (1994:38, 43-44) verwoord as hy stel dat die homogeniserende implikasie van universalisering beteken dat mense in die identiteitskeurslyf van 'n spesifieke hegemoniese kultuur beland. In werklikheid word net van die minderheids- of onderdrukte kulture verwag om 'n vreemde vorm aan te neem. Die idee van 'n neutrale kultuur is dus op 'n subtiele en selfs onbewuste manier hoogs diskriminerend.

Die bekende Richard Rorty huldig onverbloemd die historistiese argument dat partikulariteit veruniversaliseer kan word. Rorty (1991a:207-209; 1999a:236-239) stel dat "liberales wat nog nie postmodern begin dink het nie" en steeds vashou aan die Verligtingsidee dat daar iets gemeenskapliks is wat die menslike natuur genoem word en wat die idee van universele regte regverdig, 'n probleem sal hê met die parochiale begronding van 'n universalistiese liberalisme. Rorty dink egter dat daar geen ander keuse is as om te sê dat die Westerse liberalisme se ideale deur almal gevolg moet word, bloot omdat dit die beste is en nie omdat dit in ' $n$ botydse universele waarheid begrond is nie. Daar is geen transkulturele kriteria waaraan spesifieke kulture gemeet kan word nie. Ideale soos vryheid, geregtigheid en gelykheid is parochiaal, maar dit is die beste wat die mensdom tot sy beskikking het. 
Teen hierdie agtergrond van die superioriteit van die Westerse liberalisme verwerp Rorty (1991b:17-18, 23, 53-54; 1998:3, 24-25, 100-101; 1999a:229-237; 1999b:191-197) die tipies multikulturalistiese pleidooi dat ruimte gemaak word vir alle kulture om naas mekaar te oorleef. Die bewaring van verskille, sê hy, is in die pad van die gemeenskaplikheid wat nodig is vir ekonomiese gelykheid hy sien ekonomiese gelykheid as die sentrale politieke vraagstuk. Die argument dat verskille gehandhaaf moet word asof dit 'n weerspieëling is van die metafisiese noodsaak vir 'n gelyktydige vashou aan die "een en die vele" of "identiteit en verskil", maak hy af as 'n kunsmatig metafisiese probleem. Hy voorsien dus dat 'n proses van homogenisering moet plaasvind, Later, oënskynlik vanwee kritiek teen hom, voeg hy egter by dat hy eintlik slegs bedoel het dat gehomogeniseer moet word tot die liberale ideaal van vryheid wat wel nog individuele en groepsverskille toelaat. Hy baseer die proses van homogenisering op die idee van 'n "progressiewe evolusie" wat 'n kompetisie tussen alternatiewe lewensvorme veronderstel. Hierdie eindelose stryd sal uiteindelik uitloop op nuwe en meer harmoniese kulture. Rorty gee toe dat so 'n homogeniseringsproses vir vele gewelddadig sal wees en vra daarom dat 'n liberale mededoë betoon word aan diegene wat gebuk gaan onder hierdie gewelddadigheid. Tog stel hy nie 'n alternatief voor wat die geweld kan vermy nie.

Rorty maak hom skuldig aan 'n dualistiese siening oor die verhouding tussen universaliteit en partikulariteit. Aan die een kant reduseer hy dit wat bestaan na 'n evolusionêre proses wat net partikulariteite produseer en probeer hy ontslae raak van enige universele voorwaardes vir bestaan. Tog sien hy 'n veruniversele ideaal in waardes soos ekonomiese gelykheid, omdat dit die ruimte bied vir 'n klaslose utopie aan die bopunt van die evolusieproses.

Rorty se standpunt huisves ook ander spannings wat die dualisme versterk. Eerstens ondermyn die pynlike homogeniseringsproses wat hy voorsien en tot 'n mate verdra, sy (Rorty, 1993:xv, 74) eie siening dat die (universele) kernuitgangspunt van liberalisme is om wreedheid en lyding teen te staan. Sy toegewing aan 'n "gewelddadige" homogeniserende evolusieproses vir kulture en dat hy hom nie enduit laat lei deur sy fundamentele liberale uitgangspunt nie, is teleurstellend, 8 maar miskien te wagte as 'n

8 Balslev (1991:43-45) dink ook dat dit nie genoeg is dat Rorty homself net uitspreek teen onverdraagsaamheid en lyding nie, want sy uiteindelike 
skeptisisme jeens universele beginsels, sy nog meer fundamentele uitgangspunt is.

'n Volgende spanning het te doen met die feit dat Rorty aan die een kant ' $n$ eindelose progressiegeloof huldig, wat ook teenwoordig is in die kulturele evolusieproses, maar dat hy aan die ander kant ook die idee troetel dat die Westerse kultuur redelik naby aan die utopie is. Dit legitimeer 'n homogeniseringsproses wat veronderstel dat veral die nie-Westerse "ander" sal moet aanpas en evolueer. Daarteenoor sal die Westerse sentrum weinig aanpassing hoef te maak. So 'n kulturele chauvinisme kan eindig in 'n selfgenoegsame Weste wat nie agterkom dat ook haar swakhede verhard nie.

Meer nog, hoewel Rorty oënskynlik argumenteer dat kulturele partikulariteit nie belangrik is nie, is dit onderliggend 'n deurslaggewende element in sy denke. Daar is by Rorty die vooroordeel dat ander kulture nie in staat is om dieselfde ekonomiese suksesse te behaal as die Westerse beskawing nie. Fukuda-Parr (2004:5) sien in laasgenoemde vooroordeel kulturele determinisme - dit is die idee dat 'n groep se kultuur die ekonomiese prestasie en graad van demokrasie van die groep verklaar. Hy wys daarop dat die verband wat Weber tussen protestantisme en ekonomiese welvaart getrek het, asook die idee dat Confusiaanse waardes ekonomiese groei sou inhibeer almal histories verkeerd bewys is. Dieselfde is die geval met kultureel deterministiese sienings oor demokrasie, naamlik dat sekere kulture nie vatbaar is vir demokrasie nie, omdat hulle inherent outoritêr is. Met verwysing na verskeie voorbeelde, wys hy hoe gesamentlike besluitneming ook goed gewortel is in Oosterse en Afrika kulture.

Rorty se veruniversaliseerde partikularisme (historisme) kan miskien die beste getipeer word as 'n hierargiese dualisme. Aangesien hy as 'n postmetafisikus bekend wil staan, lê die oorwig van sy argumente by die idee dat daar niks universeels aan die werklikheid is om in ag te neem nie. Die histories partikuliere slaag oënskynlik daarin om volledig alle ontiese ruimtes te beset. Dit beteken dat 'n bepaalde kultuur 'n magsentrum word wat dieselfde rol speel wat metafisiese bronne in ouer filosofiese perspektiewe vervul het. Hierdie argument

standpunt oor die multikulturele situasie staan 'n goeie kans om geïnterpreteer te word as 'n vorm van kulturele imperialisme. 
keer egter nie die terugsluipende universele norme van gelykheid, vryheid, en nie-wreedheid in sy denke nie. ${ }^{9}$

\subsection{Kommunitarisme}

In die standpunte van kommunitariste kan 'n poging tot inskakeling tussen die universele en partikuliere herken word.

Friedman (1994:326, 333-334) en Van der Merwe (1999:322-323) wys op 'n spanning in hierdie poging. Kommunitariste se klem op partikulariteit toon 'n groter mate van politieke realisme as die universalisme van klassieke liberaliste. Tog is hulle poging om vas te hou aan die ideale van gelykheid en vryheid 'n aanduiding dat hulle nie met 'n suiwer partikularisme tevrede is nie. Om die waarheid te sê, dit wil voorkom asof hulle denke vasgevang is tussen konflikterende partikularistiese en universalistiese posisies.

So byvoorbeeld beskryf en verdedig Young (1995:196-197) 'n dilemma waar dit histories vir periferale groepe (vroue, swartes, homoseksueles en inheemse mense) nodig was om aan te dring op universele burgerskap en regte waarvolgens mense se partikuliere identiteite nie bereken word in die deelname aan openbare aktiwiteite nie. Dit is iets waarop hulle steeds moet aandring. Tog is daar ook ' $n$ bewustheid dat ' $n$ beheptheid met gelykheid sonder erkenning van partikuliere identiteite, dit onmoontlik maak vir die periferale groepe om werklik in aanmerking te kom vir gelyke behandeling.

Taylor (1991:46-47; 1994:26-27, 41-42) maak ook vrede daarmee dat hierdie 'n fundamentele spanning is wat kenmerkend van Westerse denke10 is. Volgens hom is die moderne universalistiese argument die resultaat van die aftakeling van premoderne sosiale hiërargieë. In 'n hiërargiese samelewing word veronderstel dat waardigheid nie iets is wat almal kan hê nie, omdat mense volgens partikuliere identiteite en funksionerings gehiërargiseer word.

Dit is implisiet ook Nussbaum (1996a:4-5) se kritiek as sy stel dat Rorty homself wel verset teen die partikulariteit van multikulturaliste, maar dan kies vir 'n Amerikaanse patriotisme. Sy wil weet hoekom kies hy nie vir 'n ware kosmopolitanisme waar menslike eenheid voorop staan nie.

10 Griffioen (1994:13) en Descombes (1994:113-114) herlei hierdie spanning terug na ' $n$ ou stryd tussen die universalisme van die Verligting en die partikularisme van die Duitse Romantici en Franse Tradisionaliste, terwyl Balslev (1991:3) en Botha (1995:161) dink dat die probleem nog ouer is en voortspruit uit ou filosofiese probleme soos die "een en die vele" sowel as "identiteit en verskil". 
Moderne mense werk egter met 'n egalitêre idee van waardigheid, wat gesetel is in 'n universeel menslike identiteit of modus. Dít, sê Taylor (1994:38-41), beteken dat daar 'n universele basis is vir die politiek van verskille: elkeen moet erken word vir sy selfgemaakte unieke identiteit.11 Tog veroorsaak die erkenning van partikulariteit inherent aan hierdie standpunt dat spesiale geleenthede gegee word aan sekere groeperings. Dit is moeilik te versoen met die eis vir universele gelykheid, omdat dit vra dat ons iets erken wat nie universeel gedeel word nie. Ons word dus gelaat met 'n indruk van dualisme tussen partikulariteit en universaliteit.

Bo en behalwe hierdie oënskynlike spanning is daar by sommige multikulturaliste ook die neiging om 'n enkele gemeenskap, en dus per implikasie 'n bepaalde lewensmodus, te sentreer. Young (1995:186-187) byvoorbeeld definieer sosiale groepe oënskynlik nietotalitêr. Groepe moet nie verstaan word asof dit 'n essensie sou hê nie, maar dit moet eerder in relasionele terme gesien word. Dit wil sê, groepe kom tot stand as gevolg van affiniteit en uitsluiting wat ontwikkel na aanleiding van situasies wat later weer kan verander. Daarby noem sy dat die meeste moderne mense aan meerdere groepe behoort. Tog meen sy ook dat die saakmakende groepe in die multikulturele situasie gesien kan word as sosiale groepe waarin 'n lid "geworpe" is. So 'n groep veronderstel 'n onderlinge "affiniteit" tussen lede, wat nie geskep word deur 'n bewuste keuse vir die groep nie, soos in gevalle waar 'n bepaalde doel nagestreef word (bv. 'n klub, korporasie, kerk of vakunie). Daarby bepaal die soort groep waarin 'n persoon onwillekeurig geworpe is, die betekenis wat die persoon aan die geskiedenis gee, die persoon se verstaan van sosiale relasies, persoonlike moontlikhede, manier van argumentering, waardes en style van uitdrukking. Young (1995:195) gaan selfs so ver as om hierdie soort groep as 'n "komprehensiewe identiteit en lewenswyse" te beskryf.

Hierdie verduideliking van Young laat ruimte vir 'n mindere intensiteit en omvattendheid van 'n gemeenskap en gemeenskapskultuur wat gebaseer is op 'n spesifieke aspek van menswees soos in die geval van volbloed partikulariste. Tog is dit ook duidelik dat die omvattendheid van die aanspraak deur 'n bepaalde menslike funksionering, asook 'n spesifieke manifestering daarvan op 'n

11 Hierdie erkenning van die universaliteit van partikulariteit as 'n basiese argument vir multikulturalisme, word oor waargeneem deur De Dijn (1997:147), Kymlicka (1997:20-21), Van der Merwe (1999:322) en Wolterstorf (1995:210211). 
persoon se lewe, taamlik totalitêr kan wees. So 'n semi-totalitarisme sal 'n mens weereens laat met die indruk van 'n dualisme; dat nie daarin geslaag word om alle soortlike gemeenskappe op 'n gelyke voet bymekaar in te skakel nie, omdat een gemeenskap ditself verhef bo die ander.

Vincent (2002:189) oordeel daarom dat die meeste multikulturaliste neig in die rigting van partikularisme, waarmee hy bedoel dat altyd meer groepe van 'n grotere geheel afstig ten einde 'n besondere identiteit binne 'n groepverband veilig te stel en uit te bou. Teenoor Young se onderliggende idee van 'n omvattende groep, sal dit dus beter wees om konsekwent te werk met die idee dat 'n persoon 'n veelheid oorvleuelende identiteite het en gevolglik aan 'n veelheid groepe moet en kan behoort.

Opvallend in die argumente van historiste en kommunitariste is steeds die neiging om menswees te reduseer tot enkele vermoëns ten koste van ander menslike aspekte. Young gee byvoorbeeld 'n meer omvattende rol aan 'n spesifieke soort gemeenskap, terwyl Rorty 'n hoër prioriteit aan die ekonomiese gee. Billikheidshalwe moet genoem word dat ' $n$ volledige redusering nie plaasvind soos in die geval van volbloed partikulariste en universaliste nie. Die uitverkore aspek word egter wel uitgelig en tot 'n hoë mate losgemaak van en opgestel teenoor ander menslike funksionerings.

\section{Voorwaardes vir inskakeling}

Hierbo is gesuggereer dat ' $n$ onderskeiding en definiëring van dimensies soos partikulariteit, universaliteit en multi-soortlikheid 'n eerste tree na die terapeutiese ingrype in die multikulturele situasie is. Hierby moet egter gevoeg word die identifisering van voorwaardes vir 'n samehangende verskeidenheid ten opsigte van hierdie multi-dimensionaliteit. In hierdie laaste afdeling van die artikel sal moontlike voorwaardes vir 'n wedersydse inskakeling van hierdie dimensies verken word.

Drie prominente voorwaardes is dié van neweskikking, komplementariteit12 en akkulturasie. Neweskikking word eerste aan die orde gestel.

12 Hier sluit ek aan by Griffioen $(1995: 205,223)$ se gebruik van die verhoudingskonsepte neweskikking en komplementariteit. 


\subsection{Neweskikking}

Partikulariste wat 'n spesifieke manifestering van 'n lewensmodus sentreer, veronderstel dat ander soortgelyke manifesterings nie die moeite werd is nie (of 'n bedreiging inhou) en dat dit daarom vernietig moet word deur 'n sentrale manifestering. Die berugte praktyk van etniese suiwering is 'n goeie voorbeeld hiervan. Oënskynlik minder radikaal is die universalisties-neigende strategie van kulturele homogenisering. Hierdie strategie veronderstel dat 'n gesentreerde kultuur ander kulture nie noodwendig summier vernietig nie, maar wel op subtiele (en soms minder subtiele) maniere dwing om te konformeer met die sentrum. Redusering beteken ook dat periferale menslike funksionerings (en die kulture daarrondom) as "laer" geag word. Hierdie "laeres" moet op die een of ander manier aan die gesentreerde aspekte konformeer - so asof hierdie essensiële funksie tog wel die oorspronklike bron is vir alle menslike funksionering.

Neweskikking beteken, teenoor hierdie gevalle, dat die verskeidenheid lewensmodi, die samelewingsvorme wat daarop gebaseer is en die kulture daaromheen, naas mekaar moet bestaan.

Rorty suggereer dat die Westerse beskawing aan die bopunt van die kulturele evolusieproses uitgekom het. Hierdie kultuur het tot stand gekom as die produk van 'n samelewing wat sy eie historiese manifestering veruniversaliseer. Die teenmiddel teen so 'n sentrering is dus om die verskeidenheid kulture meer geredelik deur die bril van 'n gelykwaardige neweskikking te sien.

Neweskikking beteken ook dat die verhouding tussen die universele en partikuliere nie hiërargies ten opsigte van mekaar georden kan word asof die een die oorsprong van die ander kan wees nie. Walzer (1994b:9-19) bevestig hierdie standpunt as hy die modernistiese etiek afkeurend beskryf as 'n poging om universele morele norme die fondament te maak waarop moraliteit gebou word. Vanaf die universele norme moet daar geredeneer word na die partikuliere omstandighede. Walzer wys daarop dat ons nêrens die universele vind sonder dat dit in die verpakking van die partikuliere kom nie. Hy suggereer selfs dat die partikuliere eerder die fondament kan wees, hoewel hy ook dit as 'n foutiewe aanname sien. Die punt is, nie die universele of die partikuliere kan gesien word as die fondament waarop die ander gebou moet word nie.

Toegepas op kultuur beteken dit dat ons potensiaal en die norme om kulturele style te ontwikkel, en die daadwerklike manifestering 
van hierdie universele potensiaal en norme in kultuur, eerder twee gelyke vennote is as wat die een die eenduidige bron vir die ander is.

\subsection{Komplementariteit}

Kommunitariste wend ' $n$ poging aan om 'n onderskeid te maak tussen universeel en partikulier. Die vorming van identiteit word byvoorbeeld nie net oorgelaat aan die gemeenskap nie, maar sekere universele norme (soos gelykheid en vryheid) kry ook 'n bepalende rol - daar is dus ' $n$ bewustheid van die universele eise in die agtergrond. Tog lyk dit of argumente hier uiteindelik neig in die rigting van die partikularisme en dit word veronderstel dat universaliteit en partikulariteit mekaar uiteindelik nie werklik medebepaal nie. Hierdie standpunt val vas in 'n dualisme tussen partikulariteit en universaliteit, waarvolgens 'n spesifieke "onwillekeurige" gemeenskap die meer universele skepper van kultuur word. Die bydrae van ander gemeenskappe en van veral universele en soortlike norme word grootliks uitgesluit. Die historisme van veruniversaliseerde partikulariste loop 'n soortgelyke pad. Hoewel erkenning gegee word aan ander kulture en aan die idee van multikulturaliteit, word dit in die finale stadium grootliks geïgnoreer.

Die teenmiddel is om alle dimensies as onontkombaar komplimentêr tot mekaar te sien. Hulle is tot so 'n mate verstrengel dat hulle nie sonder mekaar kan bestaan nie; die een word 'n voorwaarde vir die bestaan van die ander.

Dit beteken byvoorbeeld dat kultuur as universele soortlikheid nie sou bestaan het as dit nie manifesteer in partikuliere kulture soos Engelse, Zoeloe, Westerse of Afrika kulture nie. Omgekeerd is dit net so duidelik dat 'n Spaanse of 'n Koreaanse kultuur nie 'n waardige kultuur sou wees of selfs as 'n kultuur herken kon word as dit nie konformeer aan die soortlike norme vir kultuurwees nie.

\subsection{Akkulturasie}

Kulture, gemeenskappe en menslike funksionerings komplementeer mekaar egter nie net in die sin dat hulle voorwaardes vir mekaar se bestaan is nie. Hulle het uiteindelik ook 'n invloed op mekaar se aard en voortgaande ontplooing; hulle "kleur" mekaar se funksionering as't ware. Die taalkultuur van 'n bepaalde taalgemeenskap sal en behoort 'n invloed te hê op die kulture van ander gemeenskappe waartoe die lede van so 'n taalgemeenskap behoort. Verskeie patrone is hier moontlik. In sy kommunikasie behoort ' $n$ 
sosiale instelling (bv. 'n staat, universiteit of kerk) byvoorbeeld die voorkeurtaal van sy lede te reflekteer. Die kleur wat 'n taalgemeenskap aan ' $n$ ander sosiale instelling gee, kan natuurlik deur die taalgemeenskap misbruik word om totale beslag te lê op die beïnvloede instelling. Dit sou die uiterste van 'n volbloed partikularisme verteenwoordig.

Daar behoort dus ook deur so 'n instelling ruimte gemaak te word vir die taalverskeidenheid wat onder hierdie lede aangetref kan word. Daar kan egter ook ruimte gemaak word vir kommunikasie met en akkommodering van 'n groter gehoor buite die instelling of land. Hierdie voorsienings sal 'n invloed hê op die kultuur van die instelling, maar dit is in baie gevalle noodsaaklik vir die skep van bande wat andersins nie sou bestaan het nie.

Dit is egter juis laasgenoemde akkulturasie as voorwaarde vir verbinding wat in baie gevalle misbruik word as 'n argument en 'n praktyk wat omswaai in 'n strategie van homogenisering. In laasgenoemde gevalle is die grense en voorwaarde van akkulturasie egter reeds oorskry, omdat akkulturasie in ideale omstandighede nie 'n bedreiging vir of 'n ontkenning van voorwaardes soos onderskeid en neweskikking behoort in te hou nie.

\section{Geraadpleegde bronne}

BALSLEV, A.N. 1991. Cultural otherness: correspondence with Richard Rorty. Shimla: Indian Institute of Advanced Study.

BOHMAN, J. 1998. The globalization of the public sphere. Philosophy \& Social Criticism, 24(2/3):199-216.

BOTHA, M.E. 1995. The puzzling problem of pluralism. (In Griffioen, S. \& Balk, B.M., eds. Christian philosophy at the close of the twentieth century: assessment and perspective. Kampen: Kok. p. 159-173.)

DE DIJN, H. 1997. Politiek van de erkenning en multiculturalisme. (In Cuypers, S.E. \& Lemmens, W., reds. Charles Taylor: een mozaïek van zin denken. Kapellen: Pelckmanns. p. 141-157.)

DESCOMBES, V. 1994. Is there a politics of authenticity? Raritan, 13:102-123.

FRIEDMAN, J. 1994. The politics of communitarianism. Critical review, 8(2):297-340.

FUKUDA-PARR, S. 2004. Human development report 2004: cultural liberty in today's diverse world. New York: United Nations Development Programme.

GRIFFIOEN, S. 1994. Is a pluralist ethos possible? Philosophia Reformata, 59:11-25.

GRIFFIOEN, S. 1995. Kleine typologie van pluraliteit. (In De Boer, T. \& Griffoen, S., eds. Pluralisme: cultuurfilosofische beschouwingen. Amsterdam: Boom. p. 204-226.) 
HIMMELFARB, G. 1996. The illusions of cosmopolitanism. (In Cohen, J., ed. For love of country: debating the limits of patriotism. Boston: Beacon. p. 73-77.)

HITLER, A. 1939. Mein Kampf. London: Hurst \& Blackett.

HUNTINGTON, S.P. 2002. The clash of civilizations and the remaking of world order. London: Free Press.

KYMLICKA, W. 1997. States, nations and cultures. Assen: Van Gorcum.

MARX, K. 1959. A world without Jews. New York: Philosophical Library.

McCONNELL, M.W. 1996. Don't neglect the little platoons. (In Cohen, J., ed. For love of country: debating the limits of patriotism. Boston: Beacon. p. 79-84.)

NUSSBAUM, M.C. 1996a. Patriotism and cosmopolitanism. (In Cohen, J., ed. For love of country: debating the limits of patriotism. Boston: Beacon. p. 317.)

NUSSBAUM, M.C. 1996b. Reply to critics. (In Cohen, J., ed. For love of country: debating the limits of patriotism. Boston: Beacon. p. 131-143.)

OAKES, E.T. 1993. Attention must be paid. First things, 32:48-51. http://www.firstthings.com/ftissues/ft9304/oakes.html Date of access: 30 March 1999.

PUTNAM, H. 1996. Must we choose between patriotism and universal reason? (In Cohen, J., ed. For love of country: debating the limits of patriotism. Boston: Beacon. p. 91-116.)

ROCKEFELLER, S.C. 1994. Comment on "Multiculturalism: examining the politics of recognition". (In Gutmann, A., ed. Multiculturalism: examining the politics of recognition. Princeton: Princeton University Press. p. 87-98.)

RORTY, R. 1991a. Objectivity, relativism, and truth: philosophical papers. Vol. 1. Cambridge: Cambridge University Press.

RORTY, R. 1991b. Correspondence with Anindita Niyogi Balslev. (In Balslev, A.N., ed. Cultural otherness: correspondence with Richard Rorty. Shimla: Indian Institute of Advanced Study, in collaboration with New Delhi, Munshiram Manoharlal.)

RORTY, R. 1993. Contingency, irony, and solidarity. Cambridge: Cambridge University Press.

RORTY, R. 1998. Achieving our country: leftist thought in twentieth-century America. Cambridge: Harvard University Press.

RORTY, R. 1999a. Philosophy and social hope. London: Penguin.

RORTY, R. 1999b. Truth and progress: philosophical papers. Vol. 3. Cambridge: Cambridge University Press.

SANDEL, M.J. 1984. The procedural republic and the unencumbered self. Political Theory, 12(1):81-96.

TALJAARD, J.A.L. 1976. Polished lenses. Potchefstroom: Pro Rege.

TAYLOR, C. 1991. The malaise of modernity. Concord: Anansi.

TAYLOR, C. 1994. The politics of recognition. (In Gutman, A., ed. Multiculturalism: examining the politics of recognition. Princeton: Princeton University Press. p. 25-73.)

VAN DER MERWE, W.L. 1999. Cultural relativism and the recognition of cultural differences. South African Journal of Philosophy, 18(3):313-330.

VINCENT, A. 2002. Nationalism and particularity. Cambridge: Cambridge University Press. 
VOGEL, L. 1993. Review of "The ethics of authenticity and multiculturalism and the politics of recognition". International Journal of Philosophical Studies, $1(2): 325-335$.

WALZER, 1994a. Comment on "Multiculturalism: examining the politics of recognition". (In Gutmann, A., ed. Multiculturalism: examining the politics of recognition. Princeton: Princeton University Press. p. 99-103.)

WALZER, M. 1994b. Thick and thin: moral arguments at home and abroad. Notre Dame: University of Notre Dame Press.

WALZER, M. 1996. Spheres of affection. (In Cohen, J., ed. For love of country: debating the limits of patriotism. Boston: Beacon. p. 125-127.)

WOLTERSTORFF, N. 1995. From liberal to plural. (In Griffioen, S. \& Balk, B.M., eds. Christian philosophy at the close of the twentieth century: assessment and perspective. Kampen: Kok. p. 201-214.)

YOUNG, I.M. 1995. Polity and group difference: a critique of the ideal of universal citizenship. (In Beiner, R., ed. Theorizing citizenship. Albany: State University of New York Press. p. 175-207.)

\section{Kernbegrippe:}

multikulturaliteit

partikulariteit

samehang

universaliteit

verskeidenheid

Key concepts:

coherence

diversity

multiculturality

particularity

universality 